\title{
The first confirmed record of Mediterranean mantis, Iris oratoria (Mantodea: Eremiaphilidae) in Montenegro
}

\author{
Mihailo Vujić 1 Luka Zlatić ${ }^{1}$ \\ 1 HabiProt, Cankareva 9/13, 21000 Novi Sad, Serbia \\ Corresponding author: MihailoVujić (mihailovujic01@gmail.com)
}

Received 7 October 2021 | Accepted 3 November 2021 | Published 31 December 2021

Citation: Vujić M, Zlatić L (2021) The first confirmed record of Mediterranean mantis, Iris oratoria (Mantodea: Eremiaphilidae) in Montenegro. Travaux du Muséum National d'Histoire Naturelle “Grigore Antipa” 64(2): 97-101. https://doi.org/10.3897/travaux.64.e76249

\begin{abstract}
The Mediterranean mantis, Iris oratoria is recorded for the first time for the fauna of Montenegro. Two female specimens were collected in Donji Štoj (Ulcinj Municipality) in dry, grassy meadow. The presence of this species is not unexpected in Montenegro, given that it is widespread in Mediterranean region and neighbouring countries (Albania and Croatia).
\end{abstract}

\section{Keywords}

Balkan, diversity, fauna, mantids.

The order Mantodea counts more than 2500 predatory polyneopteran insects, distributed mainly in tropical and subtropical parts of the world. These insects play a very significant ecological role, given that mantids are predators of insects and many other smaller animals, which are considered pests (Patel and Singh 2016).

The Mediterranean mantis, Iris oratoria (Linnaeus, 1758) is a mantis species of the family Eremiaphilidae (Schwarz and Roy 2019) and its distribution includes the Mediterranean part of Europe (Spain, Portugal, France, Italy, Cyprus, and the Balkans), North Africa (Morocco, Algeria, Tunisia, Libya, Egypt, Chad), parts of West and South Asia (Turkey, Israel, Lebanon, Syria, Jordan, Iran) (Ramme 1951; Kaltenbach 1963, 1976; Demirsoy 1979; Mukherjee et al. 1995; Çiplak and Demirsoy 1997; Ehrmann 2002, 2011; Battiston et al. 2010; Mohammad et al. 2011). I. oratoria 
was introduced in the United States in the 1930s and now has established populations (Maxwell and Eitan 1998).

In the Balkans, this species has been previously registered in Albania, Croatia, Macedonia, Greece, Bulgaria, and Romania (Popov and Chobanov 2004; Battiston et al. 2010; Chobanov and Mihajlova 2010; Kment 2012; Jaskuła 2014; Romanowski and Romanowski 2014; Cazacu 2019). However, in the Balkans, the distribution of this species has not been accurately identified and many authors cited Fauna Europaea (https://fauna-eu.org/) as the source of information about known distribution. Fauna Europaea misrepresents distribution for the former Yugoslavian countries and states the presence of I. oratoria in Montenegro and Serbia (including Autonomous Provinces of Vojvodina and Kosovo and Metohija), although there is no reliable data (Heller 2013).

Iris oratoria (Linnaeus, 1758) (Fig. 1A)

Material examined: Montenegro; 2OQ⿱ Ulcinj Municipality, Donji Štoj (Copacabana Beach); $41.894659^{\circ} \mathrm{N} 19.313257^{\circ} \mathrm{E}$; altitude $2 \mathrm{~m}$ a.s.l.; 5.9.2021; leg. M. Vujić and L. Zlatić (stored in M. Vujić private collection).
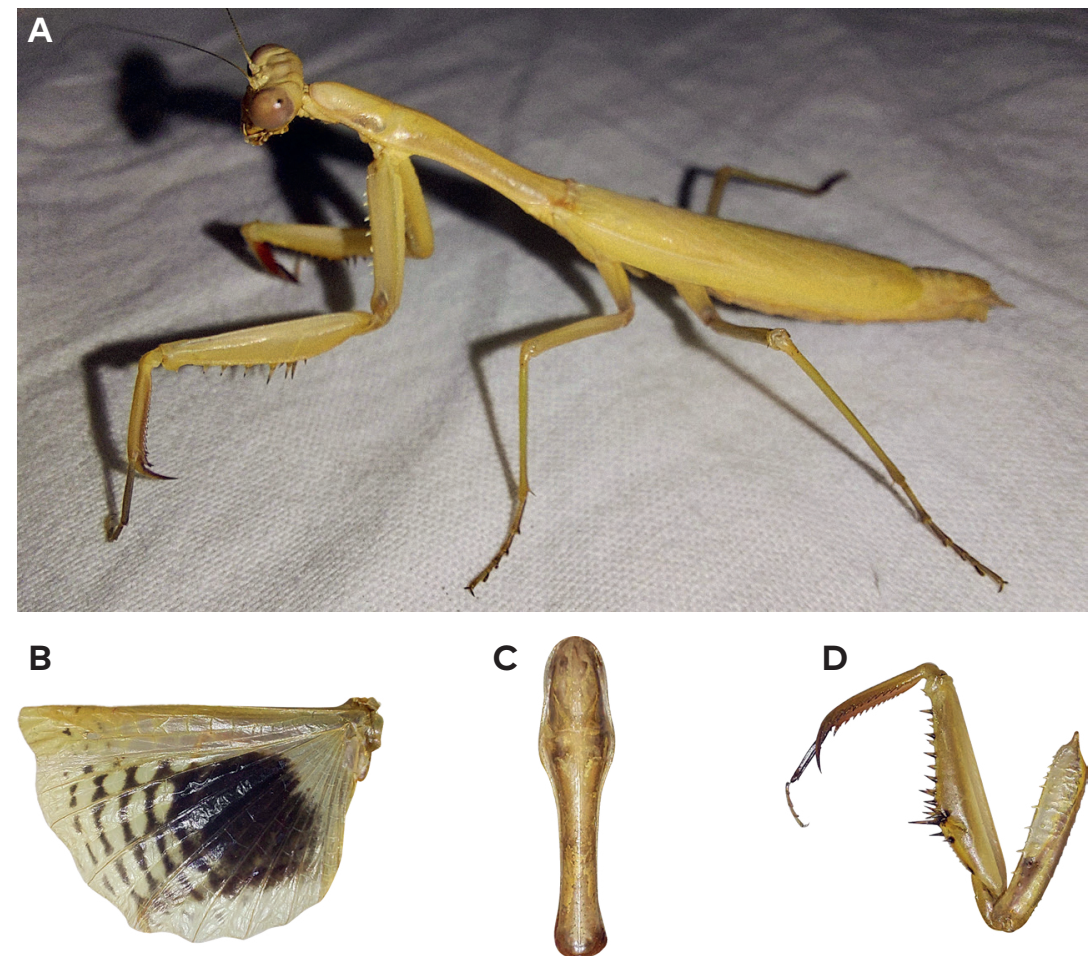

Figure 1. Iris oratoria (Linnaeus, 1758), female from Donji Štoj (Ulcinj, Montenegro). A habitus; B hind wing; C pronotum; D fore leg (photo: M. Vujić). 
Remarks: Two female, ochre colored specimens were collected during the night, in dry grass, on a meadow next to a road. At this locality, I. oratoria co-occurs with many mantodean and orthopteran species, e. g. Ameles decolor (Charpentier, 1825), Mantis religiosa (Linnaeus, 1758), Bacillus rossius (Rossi, 1790), Acrida ungarica (Herbst, 1786), Acrotylus patruelis (Herrich-Schäffer, 1838), Anacridium aegyptium (Linnaeus, 1764), Decticus albifrons (Fabricius, 1775), Sepiana sepium (Yersin, 1854), Rhacocleis germanica (Herrich-Schäffer, 1840), Tylopsis lilifolia (Fabricius, 1793) etc.

Description of habitat: The edge of a dry, grassy meadow, surrounded by Rubus sp. and Paliurus spina-christi Mill. (Fig. 2).

Diagnosis: I. oratoria can be separated from other similar Euro-Mediterranean mantids by a combination of the following characters: pronotum slender (Fig. 1C); wings: hind wings with characteristic markings (Fig. 1B), fore wings of males exceeding the abdomen, fore wings in female shorter than the abdomen (Fig. 1A); fore legs: coxae with 8-10 spines and series of tubercles along the anterior margin, femora with 5 posteroventral spines and with all spines black only at the tip (Fig. 1D) (Battiston et al. 2010). Post mortem changes can cause discoloration and darkening of femoral spines, giving them the appearance of complete or partial blackness.

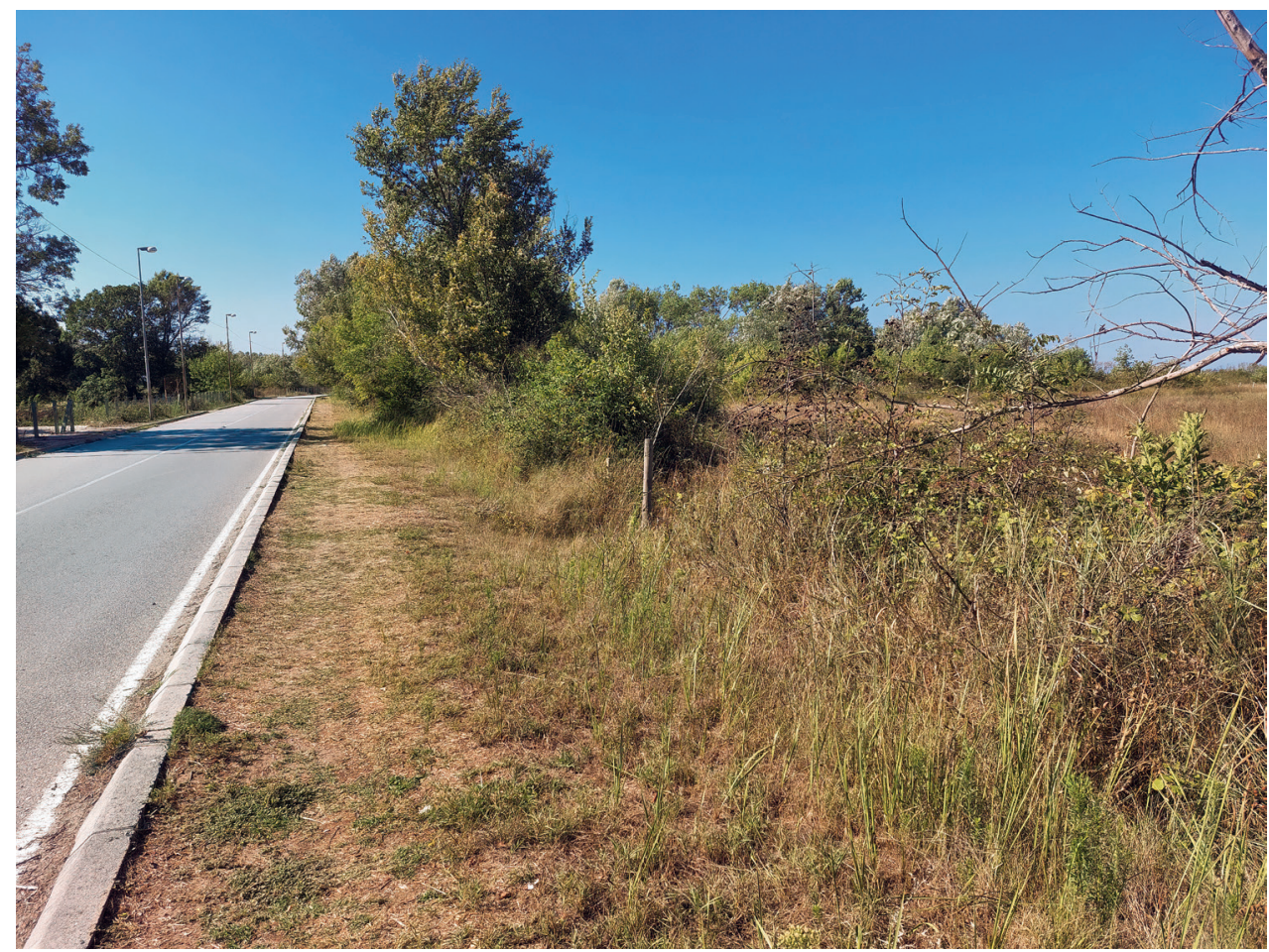

Figure 2. Donji Štoj (Ulcinj, Montenegro), the locality where Iris oratoria (Linnaeus, 1758) specimens were collected (photo: M. Vujić). 
I. oratoria is a widespread Mediterranean species, and its presence in the territory of Montenegro was expected. The finding of two specimens (both females, ochre colored) at the same locality, indicates a probable reproduction and presence of an established population. One of the collected specimens was teneral (exuvia not found). The mantis fauna of Montenegro is not well-studied and further surveys are necessary to gain insight into the real diversity of this group of organisms.

\section{Acknowledgements}

The authors are thankful to Dejan Zlatić, Lazar Radovanović, Slobodan Ivković, Aleksa Maksimović and Roberto Battiston for the technical and logistical support during the field activities and the writing of this paper.

\section{References}

Battiston R, Picciau L, Fontana P, Marshall J (2010) Mantids of the Euro-Mediterranean area. WBA Handbooks 2. World Biodiversity Association, Verona, 239 pp.

Cazacu A (2019) First record of Iris oratoria (Dictyoptera: Mantodea: Tarachodidae) in Romania. Travaux du Muséum National d'Histoire Naturelle “Grigore Antipa” 62(1): 27-30. https://doi.org/10.3897/travaux.62.e38596

Chobanov DP, Mihajlova B (2010) Orthoptera and Mantodea in the collection of the Macedonian Museum of Natural History (Skopje) with an annotated check-list of the groups in Macedonia. Articulata 25(1): 73-107.

Çiplak B, Demirsoy A (1997) Mantodea (Insecta) fauna of Malatya vicinity (Turkey) and some remarks on the mantises of Anatolia. Journal of Orthoptera Research 6: 105-111.

Demirsoy A (1979) Die Fangheuschreckenfauna Anatoliens. Entomologische Mitteilungen aus dem Zoologischen Museum Hamburg 6: 253-265. [in German]

Ehrmann R (2002) Mantodea - Gottesanbeterinnen der Welt. Natur und Tier, Münster, 519 pp. [in German]

Ehrmann R (2011) Mantodea from Turkey and Cyprus (Dictypotera: Mantodea). Articulata 26: $1-42$.

Heller KG (2013) Fauna Europaea: Mantidae. Fauna Europaea version 2017.06, https:// fauna-eu.org

Jaskuła R (2014) First Record of Geomantis larvoides Pantel, 1896 (Mantidae) from Albania with an updated checklist of Albanian Mantodea. Acta Zoologica Bulgarica 66(1): $125-126$.

Kaltenbach A (1963) Kritische Untersuchungen zur Systematik, Biologie und Verbreitung der europäischen Fangheuschrecken (Dictyoptera - Mantidae). Zoologische Jahrbücher, Abteilung Systematik, Ökologie und Geographie der Tiere 90: 521-598. [in German]

Kaltenbach A (1976) Mantodea. In: Harz K., Kaltenbach AP (Eds) Die Orthopteren Europas 3. Series Entomologica. Vol. 12, 129-169. [in German] 
Kment P (2012) First exact records of Mediterranean Mantis, Iris oratoria (Dictyoptera: Mantodea: Tarachodidae) from Croatia. Časopis Slezského zemského muzea (A) 61: 43-48.

Maxwell MR, Eitan O (1998) Range expansion of an introduced mantid Iris oratoria and niche overlap with a native mantid Stagmomantis limbata (Mantodea: Mantidae). Annals of the Entomological Society of America 91: 422-429.

Mohammad SK, Gadalla SM, El-Hamouly H, Ehrmann R, El-Den Nadder MG (2011) Mantodea of Egypt. Zootaxa 3044: 1-27. https://doi.org/10.11646/zootaxa.3044.1.1

Mukherjee TK, Hazra AK, Ghosh AK (1995) The mantid fauna of India (Insecta: Mantodea). Oriental Insects 29: 185-358.

Patel S, Singh R (2016) Updated Checklist and Distribution of Mantidae (Mantodea : Insecta) of the World. International Journal of Research Studies in Zoology (IJRSZ) 2(4): 17-54. https://doi.org/10.20431/2454-941X.0204003

Popov A, Chobanov D (2004) Dermaptera, Mantodea, Blattodea, Isoptera and Orthoptera of the Eastern Rhodopes (Bulgaria and Greece). In: Beron P, Popov A (Eds) Biodiversity of Bulgaria 2. Biodiversity of Eastern Rhodopes (Bulgaria and Greece). Pensoft \& National Museum of Natural History, Sofia, 241-309.

Ramme W (1951) Zur Systematik, Faunistik und Biologie der Orthopteren Südost-Europa und Vorderasien. Mitteilungen aus dem Zoologischen Museum in Berlin 27: 1-431. [in German]

Romanowski J, Romanowski M (2014) Mantids (Mantodea) from Pelješac Peninsula, Southern Croatia. Entomologia Croatica 18(1-2): 7-11.

Schwarz CJ, Roy R (2019) The systematics of Mantodea revisited: an updated classification incorporating multiple data sources (Insecta: Dictyoptera). Annales de la Société entomologique de France (N.S.) 55(2): 101-196. https://doi.org/10.1080/00379271.2018. 1556567 